\title{
Chapter 14 \\ Approaches of Engineering Pedagogy \\ to Improve the Quality of Teaching \\ in Engineering Education
}

\author{
Steffen Kersten
}

\subsection{Understanding of "Engineering Pedagogy"}

Engineering pedagogy has a very long tradition at Technische Universität Dresden. The discussion on technical education and technical teacher training at TU Dresden (at that time Royal Technical Educational Establishment in Dresden) can be retraced to 1851 . With the establishment of the Institute for Engineering Pedagogy by Hans Lohmann in November 1951, teaching and research in the field of engineering pedagogy were finally institutionalised. Lohmann focused his research on the relationship of technology and technical teaching. Therewith he laid the foundations for an understanding of engineering pedagogy, the purpose of which is the targeted design of technical and technologically specific teaching and learning.

A central role in Lohmann's approach of engineering didactics was played by the concept of technology. He defined technology by its function "to transform the natural world" (cp. Lohmann 1954, p. 619). The task of an engineer is to develop this technology. Engineers are therefore to become qualified in such a manner that they are able to solve technical design problems. In contrast to this, the activity of natural scientists is focused on the discovery of relationships in the world and, thus, solving scientific knowledge problems. Invention and discovery require different ways of thinking and, thus, different methods of academic training.

Another concept of engineering pedagogy which was developed in the 1990s needs to be distinguished, though not necessarily separated, from the latter understanding. For students in engineering science courses, a future engineer's ability to accomplish social communicative processes in modern structures of production and service has become a focal point of engineering pedagogical considerations.

\footnotetext{
S. Kersten $(\bowtie)$

Faculty of Education, Technische Universität Dresden, Dresden, Germany

e-mail: Steffen.Kersten@tu-dresden.de
} 
In Greek language, the etymological meaning of the term "pedagogy" includes the word "agein", which translates to the English word "lead", in addition to the word "pais" (boy). Thus, the focus of this view of engineering pedagogy is the development of teaching concepts for the preparation of future engineers for their leadership roles in changing structures of production and service. The following article is aimed primarily at an understanding of engineering pedagogy in the context of pedagogy of university engineering education.

\subsection{Concept of a Demand-Oriented "Engineering Pedagogy"}

An object-related reasoning concerning the designing of learning and teaching processes in academic engineering education illustrates the scientific character of related questions. Verifiable pedagogical and/or psychological qualifications are legally fixed requirements for a teaching career at all levels and in all types of schools of general and vocational education. In contrast, in the sector of higher education, it is assumed that lecturers have teaching abilities due to their high academic qualifications.

Evaluation results regarding the teaching quality in higher education significantly show this assumption to be only partially correct (cp. Krempkow et al. 2006). A major reason for this is the complexity of the influence factors and relationships concerning the design of a demand-oriented education in engineering sciences. In this context, the term "design" includes planning, implementation, and evaluation of teaching and learning in engineering education.

The requirement to gear engineering education to the demands of the economy, which is determined by the specifics of the engineering labour, is meant when speaking about demand-oriented and employment-based engineering education, respectively. Requirements are understood as necessary personal dispositions for successfully managing the profession-specific work activities. They are thus determined by the prevailing structures of production and service. The change from Tayloristic production structures to structures of lean production in the past 40 years has considerably changed the engineering activities and with them the requirements on engineers. A reference in this context is a study by Frieling (1993), who investigated these changes in the German automotive industry in the 1990s in detail and characterised the new production structures as follows:

- Process-chain-oriented company organisation instead of functional hierarchies

- Customer orientation instead of product orientation

- Responsibility for the project/venture and budget instead of hierarchically structured task management

- Working in teams or groups instead of working alone

- Complete operations instead of individual/single acts

- Self-regulation instead of standardised input/guidelines 


\section{Influence factors of engineering education}

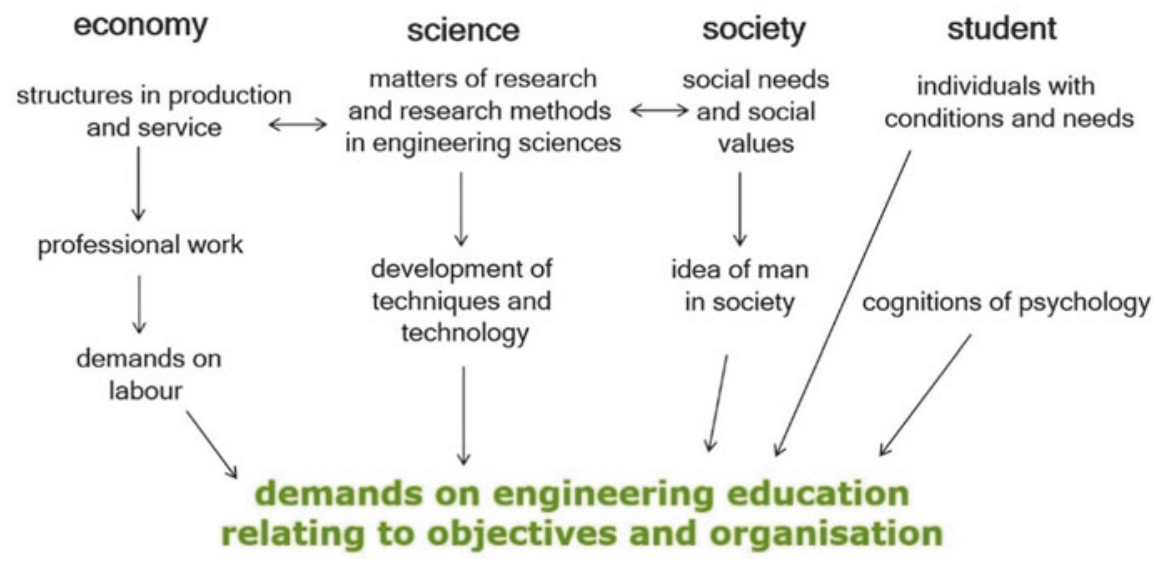

Fig. 14.1 Factors influencing on demand-oriented design of engineering education (Kersten et al. 2011, p. 3)

- Involvement instead of heteronomy

- Continuous improvement instead of hope for innovation. (id., Frieling 1993, p. 32)

Modern engineering education has to consider these developments in its curricula and training methods (Fig. 14.1).

In addition to these dynamic requirements, a variety of stable long-term requirements related to the personality dispositions of engineers result from typical engineering activities. An example is the typical way engineers think/reason. For instance, in the analysis or the design of technical systems, the thinking in the categories of "part-whole" in the relationship between structure and function plays a vital role. The calculation of technical systems by deductive structures of thinking is based on trusted statements or laws. However, in technologically diagnostic processes, progressive-reductive patterns of thought in cause-effect relationships play an essential role. Such considerations lead to scientifically based decisions for teaching methods in engineering education in order to support the development of such structures of thinking.

A second major factor influencing the training of engineers is the field of engineering sciences itself. A scientific discipline is defined by its particular matters and methods of research. Regarding the matters of engineering sciences, the terms technique and technology play a key role. Technique and technology contain processes of change (form and structure), transport, and storage of material, energy, and information (cp. Wolffgramm 1994). The views on what technique is and which function it has in relation to nature and society is also subject to changes. A change of the matter of a scientific discipline has an impact on teaching in this discipline. The systems of statements in engineering sciences (descriptive matters), the systems of 
typical action rules for engineering activities (regulatory matters), and the systems of typical standards for engineering activities (normative matters) are different from those of 60 years ago. Without adaption, Lohmann's approach to teaching technology is likely to fall short of meeting the requirements of modern engineering education. However, it can be considered a suitable starting point for the development of modern concepts of engineering education.

Closely related to the term "technology" is the society as a factor influencing engineering education. Technique not only arises from the application of natural laws and theories in engineering sciences but is also part of the technical possibilities and the socially desirable aims (cp. Heidegger and Rauner 1991, p. 20). In this respect, the development of technique and technology is also driven by social needs. In addition, a society also has an idealised image of its members. Maturity, ability to be democratic, and willingness to active shaping are just a few personality traits that are included in this ideal. From this follows the educational mission of our universities as well.

The fourth important factor influencing engineering education is the low rate of success that students have at German universities, which is often explained by deteriorating levels of education in preceding educational institutions and the resultant lack of ability to study. I do not agree with such a general statement. However, even if this thesis were true, it is economically not justifiable to let half of all young people who are interested in engineering fail in their educational intentions.

So why not use concepts of engineering education which consider these changes in the anthropogenic conditions of the students and which are based on the latest findings of educational and developmental psychology in the design of teaching and learning in higher education? Perhaps the obstacle is the inadequate funding of universities and the resulting poor student-teacher ratio but certainly also to the largely inadequate insight of the teaching staff at universities in these complex relationships of engineering pedagogy.

\subsection{Curricular Approaches of Engineering Pedagogy}

Qualified engineering activities are the foundation of any long-term economic development. Therefore, the prime task of universities is to provide academically trained professionals for the economy. The economic development of the world, with its associated increase of more qualified activities in manufacturing, services, and research, increasingly require well-trained engineers that meet the requirements of the economy and society. To this end, the discussion about curricular approaches of engineering pedagogy will contribute by improving the quality of academic engineering education.

The discussion of qualification concepts for teachers in engineering education is not new. Founded in 1951, the Institute for Engineering Education was primarily responsible for the qualification of teachers for the GDR's engineering education. In connection with the 3rd Higher Education Reform of the GDR, university 
Table 14.1 IGIP - curriculum engineering pedagogy

\begin{tabular}{l|l|l}
\hline & Module description & CPs at least* \\
\hline & Totally & 20 \\
\hline MC1 & Core modules & 7 \\
\hline MC2 & Engineering education in theory & 2 \\
\hline MC3 & Engineering education in practice & 3 \\
\hline & Laboratory didactics & 2 \\
\hline MT4 & Theory modules & 5 \\
\hline MT5 & Psychology & 2 \\
\hline MT6 & Sociology & 1 \\
\hline MT7 & Engineering ethics & 1 \\
\hline MP4 & Intercultural competence & 1 \\
\hline MP5 & Practice modules & 5 \\
\hline MP6 & Presentation and communication skills & 2 \\
\hline MP7 & Scientific writing & 1 \\
\hline & Working with projects & 1 \\
\hline ECP8 & ICT in engineering education & 1 \\
\hline ECP9 & Elective modules (1 CP per subject) & 3 \\
\hline ECP10 & Evaluation of student performance & 1 \\
\hline ECP11 & Quality management & 1 \\
\hline ECP12 & Portfolio assessment & 1 \\
\hline ECP13 & Creative thinking & 1 \\
\hline ECP14 & Coaching and mentoring in education & 1 \\
\hline ECP15 & Collaborative work & 1 \\
\hline & Teaching subject in English (CLIL) & 1 \\
\hline & Info literacy & 1 \\
\hline & & 1 \\
\hline & c & \\
\hline & & \\
\hline & & \\
\hline
\end{tabular}

* One credit point corresponds to 25 to 30 hours of work. http://www.igip.org/igip/ing-paed-igip

pedagogical qualifications became a compulsory prerequisite for a teacher's license at universities (GdDDR 1968). In the following years, the East German universities developed appropriate training concepts in order to comply with this law. This historical aspect of German university pedagogy has, in my opinion, not been exhaustively scientifically investigated.

With the founding of the International Society for Engineering Pedagogy (IGIP) in 1972, the first European body was created to coordinate the discussion about appropriate engineering pedagogical qualifications. Adolf Melezinek has very great merits in this respect. The decades-long international exchange on questions of engineering pedagogy led to a curriculum on the basis of which 35 accredited training centres are now offering further education for an "International Engineering Educator (IGIP)". The modular-structured curriculum addresses a very broad target group (engineering students, university lecturers, vocational school teachers), which, however, does not take into account the features of specific professional fields. Nevertheless, a standard has been developed with this curriculum, which forms the basis for many national approaches. Currently, various universities from all continents of the world are working to provide special modules for this curriculum for an online study (Table 14.1). 
One of the accredited training centres for "International Engineering Educator (IGIP)" study courses is the TU Dresden Institute of Vocational Education. Financed by the European Social Fund, we had the opportunity to develop and test a needsoriented continuing education course for academic teachers in the field of engineering science between 2010 and 2012. We are currently continuing this work in cooperation with Chilean universities. On the basis of empirical data collection at the University of Applied Sciences Zittau/Görlitz and the Universidad Autònoma de Chile, the following needs in the field of engineering didactics were identified:

1. "Theoretical and practical knowledge about the didactics for the teaching and learning process in engineering"

2. "Evaluation and assessment of the students' learning achievements"

3. "Knowledge about how to design effective measurements of the learning accomplishments"

4. "Didactics principles for the teaching and learning processes in engineering"

5. "Knowledge of special forms for teaching at the university level"

6. "Organisation of teaching and learning processes for the scientific formation of engineers"

7. "Use of didactic resources and of information and communication technologies (ICTs)"

8. "Knowledge about the procedures for the recollection and measurement of the learning achievements"

9. "Analysis about the concrete activity of engineering and the knowledge coming from the engineering sciences"

10. "Knowledge about the scope of action of didactic resources"

11. "Structuring of teaching and learning processes for the scientific formation of engineers"

12. "Knowledge about the design of didactic resources for the teaching and learning process"

13. "Knowledge and ability for the preparation, execution and feedback of the teaching process"

14. "The fundamentals to determine the technical subject matters within the field of engineering" (Kersten et al. 2015, p. 6)

These empirical investigations formed the basis for the development of a curriculum for an advanced training course in the field of engineering pedagogy, which has been evaluated as a success several times at German, Chinese, and Chilean Universities in recent years.

The different modules are systematically based on each other. All modules are aimed at the development of scientifically based, application-oriented action rules for the planning, execution, and analysis of academic teaching and learning in engineering sciences. The didactic concept of the training programme provides teachinglearning arrangements in coordinated phases of classroom study, self-directed learning, as well as individual coaching (cp. Fig. 14.2). 

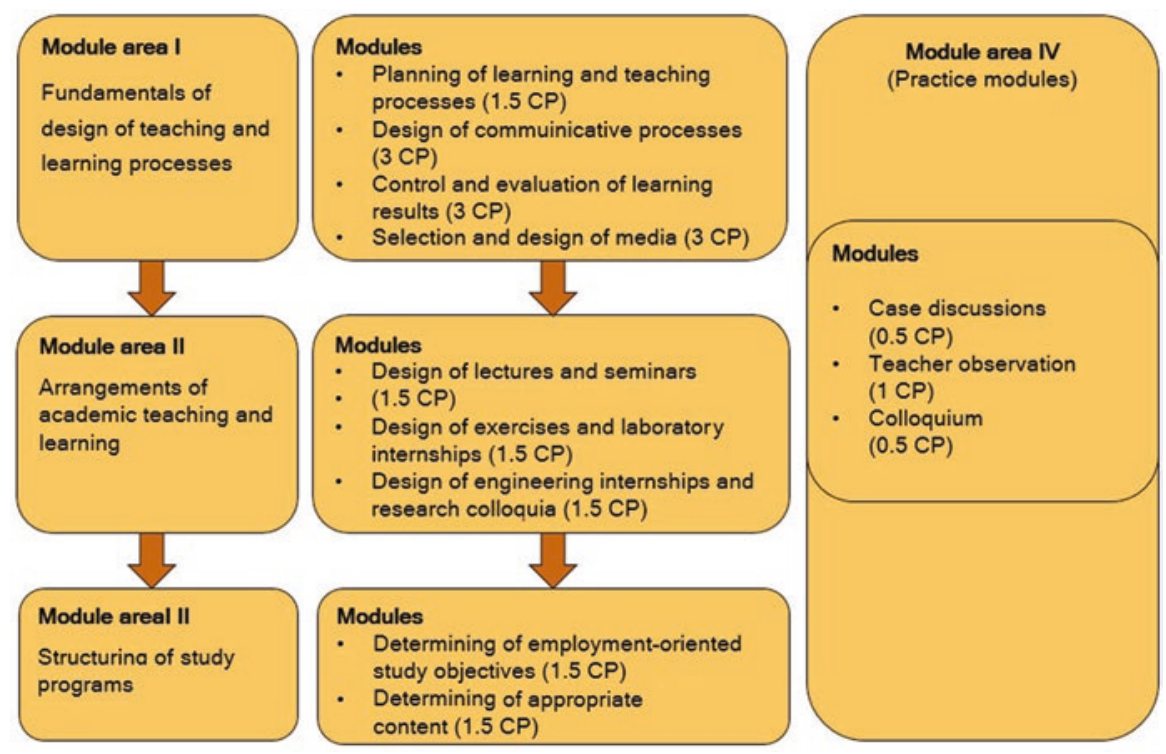

Fig. 14.2 Developed curricular structure for the university didactical qualification of teaching staff in engineering sciences (Köhler et al. 2013, p. 19)

In particular, the phases of self-directed learning and individual coaching are supported by Internet-based learning scenarios. The selection of the e-learning tools is determined exclusively by their didactic purpose and functions.

All modules are represented in a contemporary learning content management system. These are arranged similar to the course structure and include the multimedia-based learning materials. This includes the learning content, exercises of varying difficulties, examples of teaching and learning scenarios, and tests. In addition, extensive tools for communication between learners and experts are available: chat, forum, wiki, email, podcasts, and blogs. The participant can store their files in a private folder and document their progress in a portfolio. In addition to designed and managed online courses with extensive features, it is also possible to form individual online learning and working groups. The managing of the course content, the access control, and the communication can be done by the teaching staff or by skilled management personnel. For mobile learning, a special mobile version is made available (cp. Fig. 14.3).

The demand-oriented advanced training is accredited both by the International Society for Engineering Education (IGIP) and by the Scientific Society for Engineering Education (IPW). The detailed module manual can be read in Köhler et al. (2013).

The focus of the current discussion on the pedagogical further training of academic teachers of engineering sciences is a curriculum approach of the Scientific Society of Engineering Education (IPW). Under the leadership of Gudrun Kammasch, an international work group of specialists from different scientific 


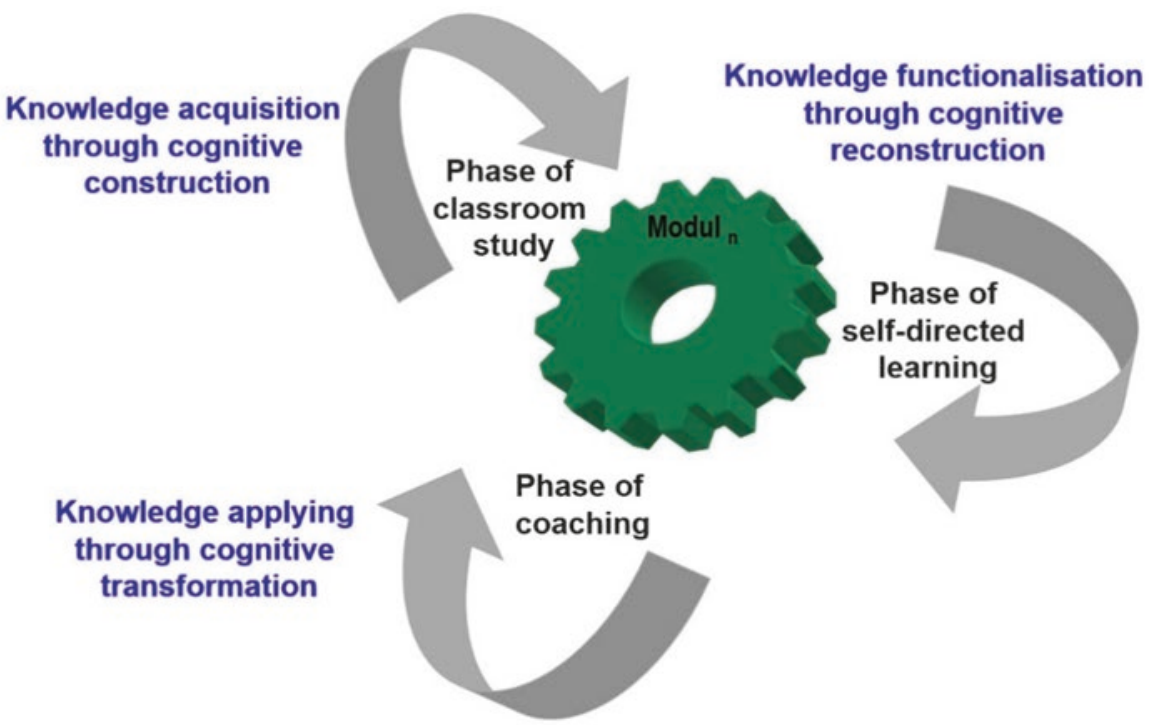

Fig. 14.3 Structure of a learning and teaching arrangement (Hortsch et al. 2003, p. 65)

disciplines has designed an engineering pedagogy curriculum and presented it in Eindhoven at the annual conference of the society 2015.

The starting point of curriculum development includes the guiding principles of a scientific, humanistic, and intercultural engineering education (cp. Fig. 14.4).

- "Promoting technical education for a comprehensive sustainable development in the sense of European and external European humanism

- Respecting the diversity of scientific traditions and developments in different cultures - promoting a fruitful scientific exchange

- Importance of practice for the learning process, for the study and in the working world

- Interpersonal relationship as the basis of teaching and learning

- Strengthening the personality of students in the sense of ability to be creative and judgmental as well as a high level of 'self-activity'

- In this sense, technical education has a civic, social and cultural perspective." (Ingenieurpädagogische Wissenschaftsgesellschaft IPW 2016, p. 250)

These typical fields of activity of a university lecturer in engineering sciences, the resulting requirements, as well as the demonstrated guiding ideas led to the following modular structure of the advanced training in engineering pedagogy.

Engineering pedagogical colloquium at the end of the curriculum. The detailed module manual can be read in Ingenieurpädagogische Wissenschaftsgesellschaft IPW (2016, p. 255)

Comparing the three curriculum drafts of the IGIP, the TU Dresden, and the IPW, we can find similarities and differences. An essential commonality lies in the extent of the further training. The IGIP has defined this as $20 \mathrm{CP}$ and thus created an 


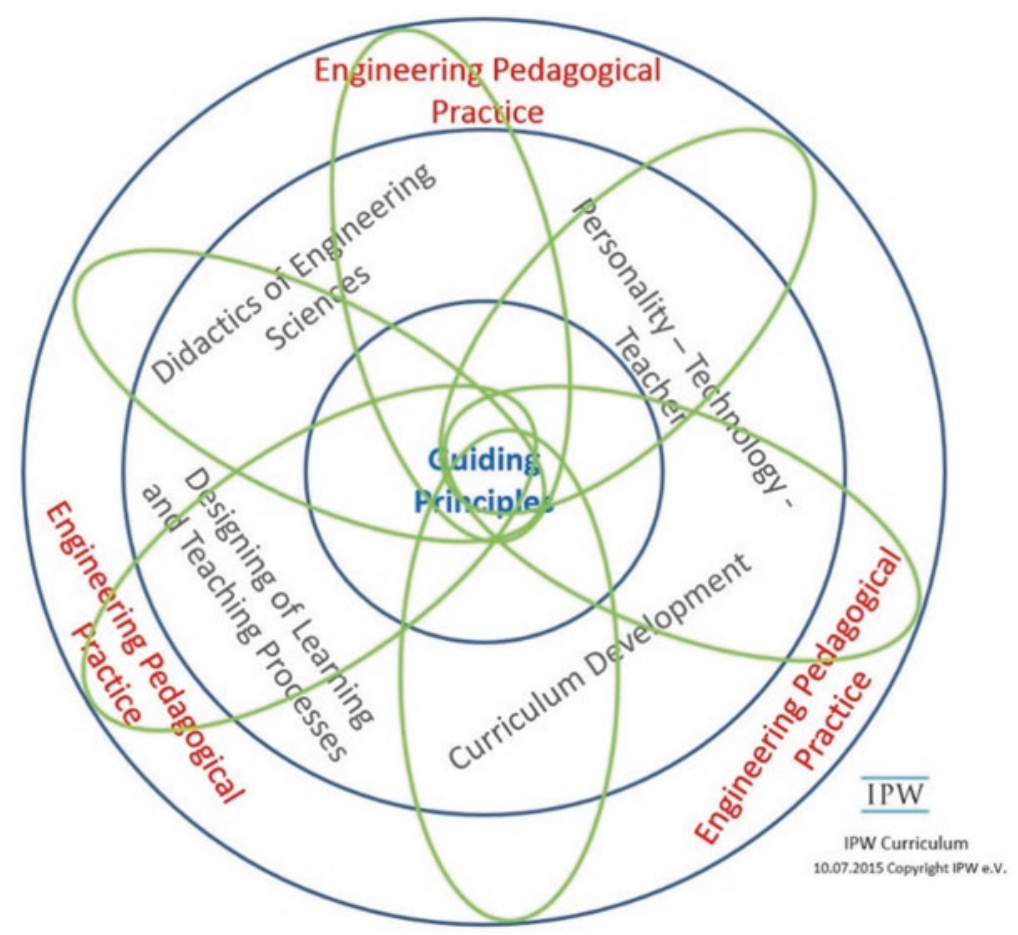

Fig. 14.4 IPW - curriculum design - engineering pedagogy theory and practice (Ingenieurpädagogische Wissenschaftsgesellschaft IPW 2016, p. 249)

accepted standard. The recommended for the presence time is $200-250 \mathrm{~h}$. The observance of these formal standards was one of the prerequisites for the accreditation of the TU Dresden curriculum by the IGIP International Monitoring Committee (cp. Table 14.2).

The IGIP curriculum follows a classical study structure. First, discipline-oriented foundations (pedagogy, psychology, sociology) are taught, followed by selected applications (project work, communication, etc.). The typical fields of activity of a university lecturer and the related requirements are not recognisable in this curriculum. The reason is the openness of the target group. With its former President, Melezinek, IGIP has a great radius of influence in Eastern Europe. In Eastern Europe, however, the term "engineering pedagogy" also includes the training of technical vocational school teachers.

The curriculum of the TU Dresden focusses very strongly on the fields of activity of university lecturers in engineering sciences. The qualification objectives were determined empirically through the analysis of activities, requirements, and needs. The developed study structure is therefore very application-oriented, though systematic. It leads from micro-didactic questions, including the psychological basis, to the curricular development of courses in engineering education. The target group here is exclusively lecturers of the engineering sciences. 
Table 14.2 Engineering pedagogical colloquium at the end of the curriculum (id., 2016, p. 251)

\begin{tabular}{l|l}
\hline "Engineering Pedagogy in Theory and Practice" & $6 \mathrm{CP}$ \\
\hline Laboratory and workshop didactics & $3 \mathrm{CP}$ \\
\hline Technology communication (scientific writing) & $3 \mathrm{CP}$ \\
\hline E-learning, use of media & $2 \mathrm{CP}$ \\
\hline Aspects from anthropology, psychology, and sociology & $3 \mathrm{CP}$ \\
\hline Control and evaluation of learning results in the engineering education & $2 \mathrm{CP}$ \\
\hline Optional modules & $1 \mathrm{CP}$ \\
\hline $\begin{array}{l}\text { Aspects of ethics in science and technology intercultural competences cross-section } \\
\text { modules (option modules) complex forms of teaching and working }\end{array}$ & $2 \mathrm{CP}$ \\
\hline Didactics of preparation for the professional life & $2 \mathrm{CP}$ \\
\hline
\end{tabular}

The IPW curriculum also focuses on the target group of teachers of engineering sciences. Although the fields of activity of the university teachers were the starting points of the discussions, they were strongly superimposed by humanistic, ethical, and intercultural aspects. The result is a very open curriculum, which can be adapted to the needs of the respective university and the respective engineering sciences.

Irrespective of the advantages and disadvantages of the illustrated curricular designs of an engineering pedagogy, the decisive positive fact is the intensive strive for the pedagogical qualification of university teachers. For a long time, the high scientific competence of a professor in their field was considered as a guarantor of quality teaching. Discussions concerning engineering pedagogical qualifications, medical pedagogical qualifications, etc., the establishment of university didactical centres, and the expansion of university pedagogical further training offers are positive signals for a rethinking in this regard.

\section{References}

Frieling, E. (1993). Das lernende Unternehmen. In E. Frieling \& U. Reuther (Eds.), Das lernende Unternehmen. Dokumentatiton einer Fachtagung am 6. Mai 1993 in München. Hochheim: BWF.

GdDDR. (1968). Anordnung über die Erteilung und den Entzug der Facultas dicendi 1004. Gesetzblatt der Deutschen Demokratischen Republik 1968.

Heidegger, G., \& Rauner, F. (1991). Berufe 2000: Berufliche Bildung für die industrielle Produktion der Zukunft. Düsseldorf.

Hortsch, H., Jentzsch, D., \& Borchardt, P. (2003). Umsetzung von unternehmensindividueller Weiterbildung in Kleinunternehmen aus dem Bereich Natur + Umwelt: zielorientiertes Coaching initiiert selbstgesteuertes Lernen (ZICONU). Teil 1. Dresdner Beiträge zur Berufspädagogik: Vol. 17. Dresden.

Ingenieurpädagogische Wissenschaftsgesellschaft (IPW). (2016). Das IPW curriculum. In G. Kammasch, A. Dehing, \& C. A. van Dorp (Eds.), Anwendungsorientierung und Wissenschaftsorientierung in der Ingenieurbildung. Wege zu technischer Bildung -10 . Ingenieurpädagogischen Regionaltagung 2016. Berlin: IPW. 
Internationale Gesellschaft für Ingenieurpädagogik (IGIP). (2016). Das IGIP curriculum: Ingenierupädagogik.

Kersten, S., Köhler, T., \& Simmert, H. (2011). e-didact - Engineering Pedagogy at Universities in Saxony - A Research and Further Education Project of TU Dresden and University of Applied Sciences Zittau/Görlitz. In M. F. Paulsen \& A. Szücs (Eds.), Learning and sustainability. The new ecosystem of innovation and knowledge; EDEN 2011 annual conference, University College of Dublin, Dublin, Ireland, 19-22 June 2011 (p. 90). Budapest: EDEN Publishers; EDEN.

Kersten, S., Simmert, H., \& Gormaz, D. (2015). Engineering Pedagogy at Universities in Chile: A research and further education project of TU Dresden and Universidad Autónoma. In European Distance and E-Learning Network (EDEN) (Ed.), Expanding Learning Scenarios - Opening Out the Educational Landscape. Proceedings of the European Distance and E-Learning Network 2015 Annual Conference. Barcelona, 9-12 June, 2015. Barcelona.

Köhler, M., Umlauf, T., Kersten, S., \& Simmert, H. (2013). Projekt "Ingenieurdidaktik an Sächsischen Hochschulen, e-Didact”: Projektabschlussbericht. Entwicklung, Implementierung und Evaluation einer bedarfsgerechten postgradualen ingenieurdidaktischen Zusatzqualifikation. Dresdner Beiträge zur Berufspädagogik: Vol. 33: SFPS Wissenschaftlicher Fachverlag.

Krempkow, R., König, K., \& Ellwardt, L. (2006). Studienqualität und Studienerfolg an sächsischen Hochschulen: Dokumentation zum "Hochschul-TÜV” der Sächsischen Zeitung 2006. HoF-Arbeitsberichte: 5'06. Wittenberg: HoF Wittenberg.

Lohmann, H. (1954). Die Technik und ihre Lehre- Ein Forschungsteilprogramm für eine wissenschaftliche Ingenieurpädagogik. Wissenschaftliche Zeitschrift der TH Dresden, 3(4), 602-629.

Wolffgramm, H. (1994). Technische Systeme und Allgemeine Technologie. Bad Salzdetfurth.

Open Access This chapter is licensed under the terms of the Creative Commons Attribution 4.0 International License (http://creativecommons.org/licenses/by/4.0/), which permits use, sharing, adaptation, distribution and reproduction in any medium or format, as long as you give appropriate credit to the original author(s) and the source, provide a link to the Creative Commons license and indicate if changes were made.

The images or other third party material in this chapter are included in the chapter's Creative Commons license, unless indicated otherwise in a credit line to the material. If material is not included in the chapter's Creative Commons license and your intended use is not permitted by statutory regulation or exceeds the permitted use, you will need to obtain permission directly from the copyright holder. 